Research Paper:

\title{
The Relationship Between Social Capital and Physical Activity Participation Motivation in the Elderly
}

\author{
Mohammad Reza Baladastian $^{1}$ (D), Sara Janmohammadi ${ }^{*}$ (D), Shima Haghani² ${ }^{\text {(iD }}$
}

1. Department of Community Health Nursing, School of Nursing and Midwifery, Iran University of Medical Sciences, Tehran, Iran.

2. Nursing Care Research Center, Iran University of Medical Sciences, Tehran, Iran.

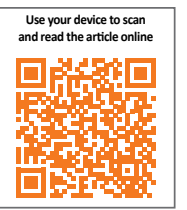

citrat on: Baladastian, M. R., Janmohammadi, S., \& Haghani, S. 2021. The Relationship Between Social Capital and Physical Activity Participation Motivation in the Elderly. Journal of Client-Centered Nursing Care, 7(3), pp. 185-194. https://doi. org/10.32598/JCCNC.7.3.370.1

https://doi.org/10.32598/JCCNC.7.3.370.1

Keywords:

Elderly, Social capital, Physical activity, Motivation

\begin{abstract}
A B S T RA C T
Background: In recent years, social capital, and especially its importance among the elderly has attracted the attention of researchers. Moreover, it was suggested that older adults lack sufficient physical activity that may be due to the lack of motivation. Accordingly, this study was conducted to determine the relationship between social capital and physical activity participation motivation among the elderly living in the west of Tehran City, Iran, in 2020.

Methods: This was a descriptive correlational study. The research population consisted of aged individuals present in the public areas of the west of Tehran City, Iran (districts 5, 9, 21, \& 22 of Tehran Municipality), such as sidewalks and passages, shopping centers, parks, mosques, and so on. In total, 400 subjects were recruited by the multistage sampling method. The Abbreviated Mental Test (AMT), Participation Motivation Questionnaire for Older Adults (PMQOA), and Onyx and Bullen social capital scale were used to gather the required data. The obtained data were analyzed by Pearson's correlation coefficient, Independent Samples t-test, and Analysis of Variance (ANOVA) in SPSS at the significance level of $\mathrm{P}<0.05$.
\end{abstract}

Results: The Mean \pm SD social capital of the study subjects was equal to $86.27 \pm 23$.3. The fitness and social factors of activity participation motives had the highest (49.72 \pm 19.34$)$ and lowest (18.97 \pm 15.96$) \mathrm{Mean} \pm \mathrm{SD}$ values (based on an index of $0-100$ ). Social capital was significantly associated with physical activity participation motivators (except fitness \& medical subscales) $(\mathrm{P}<0.05)$. Social capital was also associated with occupational status, the number of children, house size, and the economic status of the research subjects $(\mathrm{P}<0.05)$.

Conclusion: According to the obtained results, the social capital of the elderly participating in this study was pretty low. Furthermore, there was a significant relationship between social capital and the motivators of physical activity participation (apart from fitness \& medical); this result signifies the necessity of attention to the social capital of the elderly.

\section{* Corresponding Author:}

Sara Janmohammadi, MSc.

Address: Department of Community Health Nursing, School of Nursing and Midwifery, Iran University of Medical Sciences, Tehran, Iran.

Tel: +98 (21) 43651000

E-mail: goodnurse93@gmail.com 


\section{Highlights}

- The average social capital of the elderly living in the west of Tehran was pretty low.

- Social capital was associated with the motivation to participate in physical activity in the elderly living in the west of Tehran.

- Social capital was also associated with occupational status, the number of children, house size, and the economic status of the study subjects.

\section{Plain Language Summary}

Social capital and especially its importance among the elderly has attracted the attention of researchers. Moreover, it has been suggested that older adults have an insufficient physical activity which seems to be due to the lack of motivation. According to the obtained results, the social capital of the elderly participating in this study was pretty low. Also, there were substantial relationships between social capital and the motivators of physical activity participation (apart from fitness \& medical) which signifies the necessity of attention to the social capital of the elderly.

\section{Introduction}

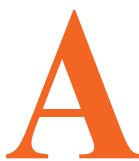

dvances in healthcare also the prevention and management of communicable diseases have increased life expectancy and the number of older people, especially in developing countries (Moradinejad et al. 2010). According to the World Health Organization (WHO), the number of people aged $\geq 60$ years will triple between 2000 and 2050 (WHO 2012). By that time, about 2 billion individuals, or $20 \%$ of the world's population, will be $\geq 60$ years (UN 2012). According to census data in 1956 , approximately $5 \%$ of the population of Iran were aged $\geq 60$ years; however, according to the latest census conducted in 2016, the number of individuals aged over 60 years in Iran is reported to be approximately 7.5 million (9.3\%) (SCI 2018a). The world's population is aging. Statistics also suggested the rapid and worrying growth of the aging phenomenon in Iran, especially in the last two decades. An aging explosion is estimated to occur in Iran, in 2031 (UNFPA 2019). It is expected that the elderly population of Iran reach $>10 \%$ by 2023 (Delshad Noghabi et al. 2013). Therefore, Iran is at risk of aging, as a very serious issue. Furthermore, the costs of caring for the elderly and improper infrastructure, also, the consequences of reducing the country's labor force are critical; an old society will suffer from a shortage of labor.

Aging is associated with anatomical, biopsychological, and other debilitating consequences. A major and influential issue on the health of the elderly is its social consequences and how they affect other problems. Besides, this period may lead to declined social relationships with others and is accompanied by isolation and depression (Domènech-Abella et al. 2018; Mousavi et al. 2015; Eftekharian et al. 2016). Social capital does not belong to a government organization or institution; however, everyone is involved in its production (Onyx \& Bullen 2000). This concept has been defined by various famous scientists and researchers (Putnam 2001; Fukuyama 1995; Cox 1997; Granovetter \& Swedberg 1986; Coleman 1988; Woolcock 1998; Portes 1998; Paxton 1999). However, the overall result of these definitions can be summarized as "a set of networks of relationships, norms, and values that facilitate the acquisition of mutual benefits".

Due to the special biopsychological needs of the elderly, developing their social capital is crucial. The absence of such relationships and networks may lead to very unfavorable results, such as depression or anxiety disorders (Domènech-Abella et al. 2018; Takechi et al. 2017). Numerous studies indicated the positive effects of social relationships on the mental health of the elderly (Berkman et al. 2014; Mulvaney-Day et al. 2007). Social isolation, improper social networks, and generally, low levels of elderly's social capital can cause mental disorders, reduced quality of life, and increased hospitalization and live in nursing homes; therefore, the importance of developing social capital in the elderly can be understood (Eftekharian et al. 2016). The relationship between social capital and health has also been identified. Emile Durkheim recognized the link between suicide rates and social cohesion (Durkheim 1888). According to Kawachi et al., social capital helps individuals to have better access to health education and information, design better health care systems, improve healthcare infrastructure, promote 
preventive efforts (disease prevention), and cultivate cultural norms that identify and introduce those that affect the health of the community (Kawachi et al. 1997). Social capital refers to the connections between the members of a network as a valuable resource that achieves the goals of the members by creating norms and mutual trust (Putnam 2001). In other words, social capital is the ability of individuals to create and promote the social network and is closely related to community health (Berkman et al. 2014; Torres et al. 2013). Social capital can have a much better effect on the health of the elderly than economic capital. Social capital can improve the health of individuals and reduce the social isolation of the elderly (Koosheshi et al. 2016). Additionally, it greatly improves the elderly's relationships and meeting their needs and prevents depression, isolation, and loneliness in them (Berkman et al. 2014; Cao \& Rammohan 2016).

Social capital includes social networks, connections between different individuals, social participation, voluntary behaviors, and trust between individuals (Putnam 2001). The concept of social capital focuses on social networks and interactions within communities and how these relationships affect health. Due to the communication role of nurses, they have a special place in social capital promotion (Lauder et al. 2006). Nurses are often involved in activities that promote relationships between individuals and communities. Accordingly, it promotes participatory activities and connects individuals to knowledge in practical and theoretical manners (Lauder et al. 2006; Burt 2009). The issue of mediation expressed by Burt (2009) well expresses the value of nurses in creating and promoting social capital. Burt believes that an individual who acts as a communicator in the field of social relations, between individuals and groups, plays a critical role in creating a network of relationships and promoting social capital. Nurses have long been a link between different groups in the health system, the health system and the social system, health professionals and patients, patients, and their families, and in general, they are an example of these link creators that facilitate the flow of information between individuals and groups (Burt 2009). Understanding social capital as a concept related to health promotion makes nurses find their role on this issue and is a method for them to add a social component to health assessment. It also acknowledges that individuals do not just have personal needs, but live in a world of interpersonal relationships (Looman \& Lindeke 2005; Hean et al. 2013). Nurses play a significant role in creating, maintaining, and promoting social capital, i.e., especially evident through the care they provide (Hean et al. 2013).
Physical activity and exercise can improve the social network of the elderly by increasing social capital (Torres et al. 2013). Moreover, regarding the effects of physical activity on mental health, investigations indicated that activity increases independence and reduces depression, isolation, and stress in the elderly (Hoseini et al. 2018). Choosing an active lifestyle in which regular physical activity and sports have a special place is among the essential strategies; due to its ability to create internal motivation and its low cost can solve multiple biopsychological problems of the elderly. Such measures help them to maintain biopsychological health at this critical period in individuals' lives (Sciamanna et al. 2017; Lok, Lok \& Canbaz 2017). Exercise or physical activity can reduce the risk of cardiovascular disease, prevent osteoporosis and diabetes, and maintain optimal body function (Koolhaas et al. 2017; Sforza et al. 2016; Lima et al. 2019; Kong \& So 2017). Additionally, there is ample evidence that regular exercise and physical activity can also affect a subject's mental health and help to reduce depression, stress, and anxiety, as common conditions in the elderly (Lok et al. 2017; Roh et al. 2015; Bhamani et al. 2015). Despite the biopsychological benefits of physical activity, numerous older people are not adequately active (Sahaf et al. 2014; Vagetti et al. 2014; Benka Wallén et al. 2015). Most elderly people have little physical activity, and in some cases, they even consider it harmful (Schuch et al. 2017; Franco et al. 2015; Hupin et al. 2015).

This inactivity may be due to a lack of activity motivation. Motivation is the driving force that leads to longterm purposeful behavior. Motivation is an inner driving force that biopsychologically leads individuals to pursue a goal to meet their needs and expectations. In other words, motivation is the inner state of a living being that leads to stimulation, continuity, energy, and direction of behavior. Several theories of motivation explain its structure, including Maslow, Herzberg, and Rogers' theory of protection motivation, which can be related to physical activity (Plotnikoff \& Trinh 2010; Rudolph 2016). Therefore, determining appropriate strategies to increase the participation of the elderly in physical activities is critical. In this regard, recognizing the effective motivational dimensions (health, social, physical fitness, etc.) of exercise and activity habits of the elderly can be a useful step to benefit them from physical activity. To understand the athletic behavior of the elderly, researchers have examined the motivational aspects of the elderly's decisions to initiate and continue physical activity. Some studies indicated that the greatest motivation for physical activity in the elderly is its positive effect on health, as well as its social benefits and pleasure (Sjörs et al. 2014; Gray et al. 2016; Gothe \& Kendall 2016; Patrícia \& Neves 2014). The results of these studies 
cannot be generalized to all the elderly; thus, further research is required to investigate the factors related to physical activity in the elderly. Besides, considering the growing elderly population, we will face serious issues about this vulnerable group and their problems. There are limited studies on social capital and physical activity (Lindström, 2011; Mummery et al. 2008; Mousavi 2016; Fu et al. 2018). Given the above and the responsibilities of community health nurses, especially concerning vulnerable groups, like the elderly, the need for this research becomes clear. Therefore, this study aimed to determine the relationship between social capital and motivation to participate in physical activity among the elderly living in the West of Tehran City, Iran, in 2020.

\section{Materials and Methods}

This was a descriptive correlational study. The research setting included public places, such as passages and sidewalks, shopping centers, parks, mosques, etc. in the west of Tehran City, Iran (districts 5, 9, 21, \& 22 of Tehran Municipality). The study population included all the elderly living in the west of Tehran who was present in the study setting. The inclusion criteria were an age of 60 years and older, no cognitive impairment characterized by the abbreviated instrument of cognitive impairment [achieving score 8 and above on Abbreviated Mental Test (AMT)], ability to communicate (the absence of hearing, speech, etc. disorders), the lack of obvious disability and movement disorders, and being literate (at least reading \& writing level).

To determine the sample size, $95 \%$ confidence level and $90 \%$ test power were considered. Moreover, we assumed that the correlation coefficient of social capital of the elderly with their participation in physical activity was at least 0.2 ; thus, this correlation was considered statistically significant, and after quantification in the following formula, the sample size was estimated as 265 . To increase generalizability, the sample size was increased by approximately $50 \%$. Therefore, the final sample size was determined to be 400 subjects who were recruited by the multistage cluster sampling method (Formula 1).

1.

$$
\begin{gathered}
n=\frac{\left(z_{1-\alpha / 2}+z_{1-\beta}\right)^{2}}{w^{2}}+3 \\
w=\frac{1}{2} \ln \frac{1+r}{1-r} \\
n=\frac{(1 / 96+1.28)^{2}}{(0 / 2)^{2}}+3=265
\end{gathered}
$$

$$
\begin{gathered}
w=\frac{1}{2} \ln \frac{1+0 / 2}{1-0 / 2}=0 / 2 \\
265+\frac{265}{2} \approx 400
\end{gathered}
$$

Demographic information questionnaire, AMT, Participation Motivation Questionnaire for Older Adults (PMQOA), and Onyx and Bullen social capital scale were used to gather the necessary data.

Demographic information questionnaire included data, such as age, gender, literacy, marital status, the number of children, people living with the elderly, having diseases, house size and status, and economic status.

Abbreviated Mental Test (AMT): The AMT was first designed by Hodkinson in the United States (Hodkinson 1972). Cronbach's alpha coefficient (0.76) was used to measure internal reliability and the intra-rater reliability method was applied to measure the external reliability of the Persian version of AMT (Bakhtiyari et al. 2014). This questionnaire has 10 questions with short answers. The correct and incorrect answers are given 1 and 0 points, respectively. The scores range between zero and 10. After evaluation, the elderly are divided into two groups with normal cognitive status $(\geq 8)$ and cognitive impairment $(<7)$ (Bakhtiyari et al. 2014). All subjects whose results were analyzed met the inclusion criteria and received a passing score on the AMT.

Participation Motivation Questionnaire for Older Adults (PMQOA): This tool was developed by Kirkby et al. (1999) and translated into Persian by Nourbakhsh et al. (2010). This questionnaire has 29 questions and is scored based on a three-point Likert-type scale (not important $=1$, moderately important $=2$, very important $=3$ ). It has 6 subscales of motivating factors in physical activity participation, including social (5 questions), fitness (5 questions), fame (5 questions), competition-benefits (7 questions), medical (4 questions), and involvement (3 questions). Each motivating factor is given a minimum of 1 and a maximum of 3 points. The scores obtained in each of these 6 motivating factors are transformed into $0-100$ index and there is no total motivation score. The higher the calculated average of each factor, the more important the motivational factor for the elderly concerning participation in physical activity. Cronbach's alpha coefficients 
for all motivational factors of the tool's Persian version were reported to range between 0.7 and 0.77 (Kholousi et al. 2018).

Onyx Social Capital Questionnaire: This scale was developed by Onyx and Bullen in 2000 in Australia. There are 36 questions in this questionnaire; the questions from 1 to 13 are related to the structural dimension, 14 to 22 concern the communication dimension, and 23 to 32 are associated with the cognitive dimension of social capital.
The last 4 questions address those who are employed. It has 3 dimensions, i.e., scored based on a 5-point Likert-type scale, as follows: very low (1 point), low (2 points), medium ( 3 points), high ( 4 points), and very high ( 5 points). The scores range from 32 and 180 and higher scores indicate greater social capital (Onyx \& Bullen 2000). This questionnaire was translated into Persian and its validity and reliability were determined, subsequently. The Internal consistency (Cronbach's alpha coefficient) for the questionnaire was measured as 0.96 (Eftekharian et al. 2016).

Table 1. Demographic characteristics of the study participants

\begin{tabular}{|c|c|c|}
\hline \multicolumn{2}{|c|}{ Characteristics } & \multirow{2}{*}{$\begin{array}{c}\text { No.(\%) } \\
147(36.8)\end{array}$} \\
\hline \multirow{4}{*}{ Age (y) } & $60-64$ & \\
\hline & $65-69$ & $135(33.8)$ \\
\hline & 70 and more & $118(29.4)$ \\
\hline & $\begin{array}{c}\text { Mean } \pm S D: 66.84 \pm 4.39 \\
\text { Max-Min: } 76-60\end{array}$ & \\
\hline \multirow{2}{*}{ Gender (76-60 (Max-Min)) } & Male & $229(57.3)$ \\
\hline & Female & $171(42.7)$ \\
\hline \multirow{4}{*}{ Literacy } & Only reading and writing & $108(27)$ \\
\hline & Less than high school & $139(34.8)$ \\
\hline & High school & $86(21.5)$ \\
\hline & Higher education & $67(16.7)$ \\
\hline \multirow{2}{*}{ Occupational status } & Working & 179(44.7) \\
\hline & Not working & $221(55.3)$ \\
\hline \multirow{3}{*}{ Marital status } & Married & $264(66)$ \\
\hline & Divorced & $4(1)$ \\
\hline & Widowed & $132(33)$ \\
\hline \multirow{4}{*}{ The number of children } & Zero & $11(2.8)$ \\
\hline & One & $133(33.3)$ \\
\hline & Two & $143(35.7)$ \\
\hline & Three and more & $113(28.2)$ \\
\hline \multirow{2}{*}{ People living with the elderly } & Spouse and/or Children & $384(96)$ \\
\hline & Alone (and other) & $16(4)$ \\
\hline \multirow{4}{*}{ Underlying diseases } & Cardiovascular & $155(38.7)$ \\
\hline & Diabetes & $103(25.7)$ \\
\hline & Musculoskeletal & $137(34.3)$ \\
\hline & No disease & $5(1.3)$ \\
\hline \multirow{3}{*}{ House size } & Lower than $60 \mathrm{~m}^{2}$ & $103(25.7)$ \\
\hline & Between 60 and $100 \mathrm{~m}^{2}$ & $153(38.3)$ \\
\hline & Higher than $100 \mathrm{~m}^{2}$ & $144(36)$ \\
\hline \multirow{2}{*}{ House status } & Owner & $245(155)$ \\
\hline & Rental & $61.3(38.7)$ \\
\hline \multirow{3}{*}{ Economic status } & Not good & $82(20.5)$ \\
\hline & Pretty good & $243(60.8)$ \\
\hline & Good & $75(18.7)$ \\
\hline
\end{tabular}


Table 2. Correlation between social capital and its dimensions and physical activity participation motivation factors

\begin{tabular}{|c|c|c|c|c|c|}
\hline $\begin{array}{l}\text { Social Capital } \\
\text { Partivity } \\
\text { Patipation Motivation }\end{array}$ & & $\begin{array}{c}\text { Structural Social } \\
\text { Capital }\end{array}$ & $\begin{array}{l}\text { Communicational } \\
\text { Social Capital }\end{array}$ & $\begin{array}{c}\text { Cognitive Social } \\
\text { Capital }\end{array}$ & Total Social Capital \\
\hline Social factor & $\begin{array}{l}r \\
P\end{array}$ & $\begin{array}{c}0.14 \\
0.005\end{array}$ & $\begin{array}{c}0.15 \\
0.002\end{array}$ & $\begin{array}{c}0.17 \\
<0.001\end{array}$ & $\begin{array}{c}0.17 \\
0.001\end{array}$ \\
\hline Fitness factor & $\begin{array}{l}r \\
P\end{array}$ & $\begin{array}{c}0.08 \\
0.075\end{array}$ & $\begin{array}{c}0.08 \\
0.082\end{array}$ & $\begin{array}{l}0.05 \\
0.253\end{array}$ & $\begin{array}{c}0.09 \\
0.054\end{array}$ \\
\hline Fame factor & $\begin{array}{l}r \\
P\end{array}$ & $\begin{array}{c}0.15 \\
0.003\end{array}$ & $\begin{array}{l}0.13 \\
0.007\end{array}$ & $\begin{array}{c}0.11 \\
0.023\end{array}$ & $\begin{array}{c}0.16 \\
0.001\end{array}$ \\
\hline Compete-benefits factor & $\begin{array}{l}r \\
P\end{array}$ & $\begin{array}{c}0.15 \\
0.002\end{array}$ & $\begin{array}{c}0.19 \\
<0.001\end{array}$ & $\begin{array}{c}0.15 \\
0.002\end{array}$ & $\begin{array}{c}0.19 \\
<0.001\end{array}$ \\
\hline Medical factor & $\begin{array}{l}r \\
P\end{array}$ & $\begin{array}{c}0.02 \\
0.658\end{array}$ & $\begin{array}{l}0.03 \\
0.492\end{array}$ & $\begin{array}{c}0.02 \\
0.656\end{array}$ & $\begin{array}{c}0.04 \\
0.429\end{array}$ \\
\hline Involvement factor & $\begin{array}{l}r \\
p\end{array}$ & $\begin{array}{c}0.11 \\
0.018\end{array}$ & $\begin{array}{c}0.17 \\
0.001\end{array}$ & $\begin{array}{c}0.15 \\
0.002\end{array}$ & $\begin{array}{c}0.16 \\
0.001\end{array}$ \\
\hline
\end{tabular}

Data analysis was performed using SPSS. Frequency distribution tables were used for the qualitative variables and the numerical indices of minimum, maximum, mean, and standard deviation were used for the quantitative variables. In the inferential statistics section, Pearson's correlation coefficient, Independent Samples t-test, and Analysis of Variance (ANOVA) were used. The significance level was set at $\mathrm{P}<0.05$.

\section{Results}

The demographic characteristics of the study subjects are presented in Table 1. The relationship between participation motivation factors and social capital and its dimensions is illustrated in Table 2. Table 3 demonstrates the significant relationships between demographic characteristics and social capital and motivation factors of the subjects.

Table 3. Significantly correlated demographic characteristics of the participants with social capital and participation motivation factors

\begin{tabular}{|c|c|c|c|}
\hline Characteristics & Main Variable & Test Result & Test Type \\
\hline Occupational status & Total social capital & $\begin{array}{l}t=3.68 \\
d f=398 \\
P<0.001\end{array}$ & Independent t-test \\
\hline \multirow{3}{*}{ The number of children } & Total social capital & $\begin{array}{c}F=6.1 \\
P<0.001\end{array}$ & \multirow{3}{*}{ ANOVA } \\
\hline & Social factor & $\begin{array}{l}F=2.84 \\
P=0.037\end{array}$ & \\
\hline & Compete-benefits factor & $\begin{array}{c}F=2.94 \\
P=0.033\end{array}$ & \\
\hline \multirow{3}{*}{ House size } & Total social capital & $\begin{array}{l}F=5.26 \\
P=0.006\end{array}$ & \multirow{3}{*}{ ANOVA } \\
\hline & Fame factor & $\begin{array}{l}F=5.48 \\
P=0.004\end{array}$ & \\
\hline & Compete-benefits factor & $\begin{array}{l}F=3.86 \\
P=0.022\end{array}$ & \\
\hline \multirow{3}{*}{ Economic status } & Total social capital & $\begin{array}{l}F=12.82 \\
P<0.001\end{array}$ & \multirow{3}{*}{ ANOVA } \\
\hline & Fame factor & $\begin{array}{l}F=16.88 \\
P<0.001\end{array}$ & \\
\hline & Compete-benefits factor & $\begin{array}{l}F=13.8 \\
P<0.001\end{array}$ & \\
\hline
\end{tabular}

Client- Centered Nursing Care 


\section{Discussion}

This study determined the relationship between social capital and physical activity participation motivation among the elderly living in the west of Tehran City, Iran. The Mean \pm SD age of the study subjects $(66.84 \pm 4.39)$ may initially seem low. However, the study population is older people who are present in public and therefore relatively active. As per Table 2, the social factor of activity participation motivation was significantly and positively related to the total social capital and its dimensions $(\mathrm{P}<0.05)$. Thus, with increasing the score of the social factor, social capital and its dimensions also elevated. In short, social capital and its dimensions presented a significant positive relationship with all activity motivation factors, except the fitness and medical factors. Social capital and its dimensions were correlated with those motivational factors of activity, i.e., to some extent related to social relations (i.e., social, fame, compete-benefits, \& involvement factors). Social context may increase physical activity levels (Kokkonen et al. 2019, Salvy et al. 2009). Lindstrom found that the social capital of 18- to 80-year-olds was related to their physical activity (Lindström 2011). Herbolsheimer et al. also concluded that low levels of social capital in older people living in the community were associated with low levels of physical activity (Herbolsheimer et al. 2017).

These results were consistent with those of the present study. However, in a study on nurses working in governmental hospitals in Yazd City, Iran, social capital was related to the level of participation in sports activities; however, this relationship could not explain a large part of the variance of the study population. Accordingly, the relationship between demographic variables and sports activities was much stronger than the relationship between social capital and these activities (Parsamehr \& Torkan 2012). There were the difference between the population, applied instruments, and the statistical analysis methods of our research and their study.

As per Table 3, the social capital of the study participants was significantly related to employment status, the number of children, house size, and their economic status. Employment status is among the factors that due to its nature can affect the number of interpersonal relationships. Employed individuals have relationships with others according to their job requirements; accordingly, this condition creates social relationships. Furthermore, lower pensions, compared to employment wages can cause financial stress. A systematic review revealed the relationship between retirement and depression, i.e., partly caused by low income in this period of life (Li et al. 2021). Nakhaie and Kazemipur's data were also congruent with ours (Nakhaie \& Kazemipur 2013).
According to the obtained results, social capital was related to the number of children of the research subjects. This can be justified by increasing the relationships of the elderly as a result of having more children. Shi considered the relationship between the number of children and parental happiness (Shi 2016). Other studies also emphasized the relationship between social capital and happiness (Rodríguez-Pose \& Von Berlepsch 2014; Bjørnskov 2008; Leung et al. 2011). This is because having more children can produce greater happiness and increase social relationships. According to the collected results, social capital was associated with house size. This issue can also be related to the happiness of the elderly. This is because a bigger house can provide more peace and comfort for the residents. The economic status of the study participants was another demographic variable that was significantly related to social capital. It has been shown that the economic status and social capital of adults are associated (Phongsavan et al. 2006). Additionally, a better economic situation can be associated with more happiness, which in turn, increases social capital. A better economic situation indicates less worry.

The relationship between the economic status and the factors of fame and compete-benefits remains debatable. As the economic situation improves, these factors became more important for the study participants. The reason for this relationship may concern social capital. In other words, as the economic situation improves, a subject's social capital increases. Besides, this increase in social capital can be reflected in increasing the importance of fame factors and competitive benefits.

\section{Conclusion}

There was a significant relationship between social capital and social, fame, compete-benefits, and the involvement components of motivational factors of participation in the physical activity of the elderly. The social capital of the examined elderly was related to their occupation status, the number of children, house size, and economic status. The fame factor of motivation to participate in the physical activity of the elderly was associated with the size of a house and their economic status. Additionally, competitive benefits were related to the number of children and economic status. The obtained results can be used to inform nurses and nursing students to pay more attention to aging. It is also possible to take effective steps to improve the levels of physical activity of the elderly by strategies to promote their social capital, which requires further research, especially in the form of field trials. By presenting the results to the health centers as well as the municipality, implementing the proposed ideas will not be out of reach. 
This descriptive research failed to identify cause-andeffect relationships. Therefore, its results should be used with caution. Moreover, the study participants' answers to the questions were self-reported and may affect the accuracy of the results.

\section{Ethical Considerations}

\section{Compliance with ethical guidelines}

This study was approved by the Ethics Committee of Iran University of Medical Sciences (Code: IR.IUMS. REC.1398.1174). Written informed consent was sought from the subjects.

\section{Funding}

This study was funded by the Iran University of Medical Sciences (IUMS). The study was extracted from the MSN. thesis of the first author at the Department of Community Health Nursing, School of Nursing and Midwifery, Iran University of Medical Sciences, Tehran.

\section{Authors' contributions}

Conceptualizaion, designing, data collecting, writing - the initial draft, and writing - revision and editing: Mohammad Reza Baladastian; Supervision: Sara Janmohammadi; Statistical consultant: Shima Haghani.

\section{Conflict of interest}

The authors declared no conflicts of interest.

\section{Acknowledgments}

The authors would like to appreciate the municipality of Tehran in districts 5, 9, 21, and 22 .

\section{References}

Bakhtiyari, F., et al. 2014. [Validation of the Persian version of Abbreviated Mental Test (AMT) in elderly residents of Kahrizak Charity Foundation (Persian)]. Iranian Journal of Diabetes and Metabolism, 13(6), pp. 487-94. http://ijdld.tums.ac.ir/article1-5271-en.html

Benka Wallen, M., et al. 2015. Levels and patterns of physical activity and sedentary behavior in elderly people with mild to moderate Parkinson disease. Physical Therapy, 95(8), pp. 1135-41. [DOI:10.2522/ptj.20140374]
Berkman, L. F., Kawachi, I. \& Glymour, M. M., 2014. Social epidemiology. $2^{\text {nd }}$ ed. Oxford: Oxford University Press. [DOI:10.1093/med/9780195377903.001.0001]

Bhamani, M. A., et al. 2015. Depression and its association with functional status and physical activity in the elderly in Karachi, Pakistan. Asian Journal of Psychiatry, 14, pp. 46-51. [DOI:10.1016/j.ajp.2014.12.004]

Bjørnskov, C., 2008. Social capital and happiness in the United States. Applied Research in Quality of Life, 3(1), pp. 43-62. [DOI:10.1007/s11482-008-9046-6]

Granovetter, M., \& Swedberg R., 2011. The Sociology of Economic Life. $3^{\text {rd }}$ ed. New York: Routledge. https://www.routledge.com/The-Sociology-of-Economic-Life/GranovetterSwedberg/p/book/9780813344553

Burt, R. S., 2009. Structural holes: The social structure of competition. The forms of capital. Cambridge: Harvard University Press. https://books.google.com/books?id=FAhiz9FWDzMC\&dq

Cao, J. \& Rammohan, A., 2016. Social capital and healthy ageing in Indonesia. BMC Public Health, 16, p. 631. [DOI:10.1186/ s12889-016-3257-9]

Coleman, J. S., 1988. Social capital in the creation of human capital. American Journal of Sociology, 94, pp. S95-120. [DOI:10.1086/228943]

Darabi, S. \& Torabi, F., 2017. [Analysis and comparison of aging population in Europe and Asia during 1950 to 2015 (Persian)]. Salmand: Iranian Journal of Ageing, 12(1), pp. 30-43. [DOI:10.21859/sija-120128]

Delshad Noghabi, A., et al. 2013. [Polypharmacy and its related factors among elderlies (Persian)]. Iran Journal of Nursing, 26(83), pp. 1-9. http://ijn.iums.ac.ir/article-1-1577-en.html

Domenech-Abella, J., et al. 2018. Anxiety, depression, loneliness and social network in the elderly: Longitudinal associations from The Irish Longitudinal Study on Ageing (TILDA). Journal of Affective Disorders, 246, pp. 82-8. [DOI:10.1016/j. jad.2018.12.043]

Durkheim, É., 1888. [Suicide et natalité: étude de statistique morale (French)]. Revue Philosophique de la France et de l'Étranger, 26, pp. 446-63. https:/ / www.jstor.org/stable/41074966

Eftekharian, R., et al. 2016. [Validity and reliability of Persian version of onyx social capital scale in elderly people (Persian)]. Salmand: Iranian Journal of Ageing, 11(1), pp. 174-89. [DOI:10.21859/sija-1101174]

Franco, M. R., et al. 2015. Older people's perspectives on participation in physical activity: A systematic review and thematic synthesis of qualitative literature. British Journal of Sports Medicine, 49(19), pp. 1268-76. [DOI:10.1136/bjsports-2014-094015]

Fu, C., et al. 2018. Association between social capital and physical activity among community-dwelling elderly in Wuhan, China. International Journal of Gerontology, 12(2), pp. 155-9. [DOI:10.1016/j.ijge.2017.10.001]

Fukuyama, F., 1995. Social capital and the global economy. Foreign Affairs, 74(5), pp. 89-103. [DOI:10.2307/20047302]

Gothe, N. P. \& Kendall, B. J., 2016. Barriers, motivations, and preferences for physical activity among female African American older adults. Gerontology $\mathcal{E}$ Geriatric Medicine, 2, pp. 1-8. [DOI:10.1177/2333721416677399] 
Gray, P. M., et al. 2016. Motives and barriers to physical activity among older adults of different socioeconomic status. Journal of Aging Physical Activity, 24(3), pp. 419-29. [DOI:10.1123/ japa.2015-0045]

Hean, S., et al. 2013. A nurse's role in promoting social capital in children and young people. Nursing Children and Young People, 25(1), pp. 19-23. [DOI:10.7748/ncyp2013.02.25.1.19.s9535]

Herbolsheimer, F., et al. 2017. Relationship between social isolation and indoor and outdoor physical activity in communitydwelling older adults in Germany: Findings from the ActiFE study. Journal of Aging ad Physical Activity, 25(3), pp. 387-94. [DOI:10.1123/japa.2016-0060]

Hodkinson, H. M., 1972. Evaluation of a mental test score for assessment of mental impairment in the elderly. Age and Ageing, 1(4), pp. 233-8. [DOI:10.1093/ageing/1.4.233]

Hoseini, T., Heydari Nezhad, S. \& Azmsha, T., 2018. [The role of motivation on the rate of participation elders in sport for all (Persian)]. Research in Sport Management \& Motor Behavior, 8(16), pp. 103-11. [DOI:10.29252/JRSM.8.16.103]

Hupin, D., et al. 2015. Even a low-dose of moderate-to-vigorous physical activity reduces mortality by $22 \%$ in adults aged $\geq 60$ years: A systematic review and meta-analysis. British Journal of Sports Medicine, 49(19), pp. 1262-7. [DOI:10.1136/bjsports-2014-094306]

Kawachi, I., et al. 1997. Social capital, income inequality, and mortality. American Journal of Public Health, 87(9), pp. 1491-8. [DOI:10.2105/AJPH.87.9.1491]

Kholousi, P., Tojari, F. \& Esmaeili, S. M. R., 2018. [Determining motives and motivation factors among Iranian elders of male and female to participate in physical activities (Persian)]. Strategic Studies on Youth and Sports, 17(40), pp. 27-42. http:// faslname.msy.gov.ir/article_254.html

Kirkby, R. J., et al. 1999. Exercise in older women: Motives for participation. Australian Psychologist, 34(2), pp. 122-7. [DOI:10.1080/00050069908257440]

Kong, S. \& So, W. Y., 2017. Gender differences in body composition, physical activity level, physical fitness, and bone mineral density among elderly individuals living alone compared to those living with their spouses. Journal of Men's Health, 13(2), pp. 60-7. [DOI:10.22374/1875-6859.13.2.8]

Kokkonen, J., et al. 2019. Effectiveness of a creative physical education intervention on elementary school students' leisure-time physical activity motivation and overall physical activity in Finland. European Physical Education Review, 25(3), pp. 796-815. [DOI:10.1177/1356336X18775009]

Koolhaas, C. M., et al. 2017. Impact of physical activity on the association of overweight and obesity with cardiovascular disease: The rotterdam study. European Journal of Preventive Cardiology, 24(9), pp. 934-41. [DOI:10.1177/2047487317693952]

Koosheshi, M., et al. 2016. [The effect of social capital on the health of the elderly with 60 or more years of age in Mashhad urban districts (Persian)]. Journal of Social Sciences, 13(1), pp. 109-29. [DOI:10.22067/JSS.V1311.52668]

Lauder, W., et al. 2006. Social capital, rural nursing and rural nursing theory. Nursing Inquiry, 13(1), pp. 73-9. [DOI:10.1111/ j.1440-1800.2006.00297.x]
Leung, A., et al. 2011. Searching for happiness: The importance of social capital. Journal of Happiness Studies, 12(3), pp. 443-62. [DOI:10.1007/s10902-010-9208-8]

$\mathrm{Li}, \mathrm{W}$., et al. 2021. The longitudinal association between retirement and depression: A systematic review and meta-analysis. American Journal of Epidemiology , kwab125. [DOI:10.1093/aje/kwab125]

Lima, A. P. D., et al. 2019. Physical activity is associated with knowledge and attitudes to diabetes Type 2 in elderly. Journal of Physical Education, 30(1), pp. 1-10. [DOI:10.4025/jphyseduc. v30i1.3017]

Lindström, M., 2011. Social capital, desire to increase physical activity and leisure-time physical activity: A populationbased study. Public Health, 125(7), pp. 442-7. [DOI:10.1016/j. puhe.2011.01.015]

Lok, N., Lok, S. \& Canbaz, M., 2017. The effect of physical activity on depressive symptoms and quality of life among elderly nursing home residents: Randomized controlled trial. Archives of Gerontology Geriatrics, 70, pp. 92-8. [DOI:10.1016/j. archger.2017.01.008]

Looman, W. S. \& Lindeke, L. L., 2005. Health and social context: Social capital's utility as a construct for nursing and health promotion. Journal of Pediatric Health Care, 19(2), pp. 90-4. [DOI:10.1016/S0891-5245(04)00277-9]

Moradinejad, S., et al. 2010. [The effect of reminiscence therapy on elderly mental health (Persian)]. Salmand: Iranian Journal of Ageing, 5(3), pp. 60-6. http://salmandj.uswr.ac.ir/article1-280-en.html

Mousavi, S. M., 2016. [Relationship between social capital and physical activity among the elderly referred to health centers in the city of Kerman in 2015 (Persian)] [PhD. dissertation]. Kerman: Kerman University of Medical Sciences. http:/ / eprints. kmu.ac.ir/25750/2/5715.pdf

Mousavi, S. M., Haghi, M. \& Gharasi Manshadi, M., 2015. Iran's health system and readiness to meet the aging challenges. Iranian Journal of Public Health, 44(12), pp. 1716-7. [PMID][PMCID]

Mulvaney-Day, N. E., Alegria, M. \& Sribney, W., 2007. Social cohesion, social support, and health among Latinos in the United States. Social Science \& Medicine, 64(2), pp. 477-95. [DOI:10.1016/j.socscimed.2006.08.030]

Mummery, W. K., et al. 2008. Associations between physical inactivity and a measure of social capital in a sample of Queensland adults. Journal of Science Medicine in Sport, 11(3), pp. 308-15. [DOI:10.1016/j.jsams.2007.06.002]

Nakhaie, M. R. \& Kazemipur, A., 2013. Social capital, employment and occupational status of the new immigrants in Canada. Journal of International Migration and Integration, 14(3), pp. 419-37. [DOI:10.1007/s12134-012-0248-2]

Nourbakhsh, M., et al. 2010. [The comparison of participation motives of male and female older adults for sport activities in Tehran (Persian)]. Journal of Development and Motor Learning, 2(2), pp. 49-69. https://jmlm.ut.ac.ir/article_23802_2319.html?lang=en

Onyx, J. \& Bullen, P., 2000. Measuring social capital in five communities. The Journal of Applied Behavioral Science, 36(1), pp. 23-42. [DOI:10.1177/0021886300361002] 
Parsamehr, M. \& Torkan, R., 2012. [A Survey about the relationship between social capital and sport's activities in participation (Persian)]. Iranian Journal of Nursing Research, 7(26), pp. 69-79. http://ijnr.ir/article-1-1058-en.html

Patrícia, A. \& Neves, R., 2014. Physical activity-the attitude of the institutionalised elderly. Journal of Physical Education Sport, 14(1), pp. 12-5. https:/ / www.researchgate.net/publication/261056191_Physical_activity_-_the_attitude_of_the_institutionalized_elderly

Paxton, P., 1999. Is social capital declining in the United States? A multiple indicator assessment. American Journal of Sociology, 105(1), pp. 88-127. [DOI:10.1086/210268]

Phongsavan, P., et al. 2006. Social capital, socio-economic status and psychological distress among Australian adults. Social Science $\mathcal{E}$ Medicine, 63(10), pp. 2546-61. [DOI:10.1016/j.socscimed.2006.06.021]

Plotnikoff, R. C. \& Trinh, L., 2010. Protection motivation theory: Is this a worthwhile theory for physical activity promotion? Exercise Sport Sciences Reviews, 38(2), pp. 91-8. [DOI:10.1097/ JES.0b013e3181d49612]

Portes, A., 1998. Social capital: Its origins and applications in modern sociology. Annual Review of Sociology, 24(1998), pp. 1-24. [DOI:10.1146/annurev.soc.24.1.1]

Putnam, R. D., 2001. Bowling alone: The collapse and revival of American community. New York: Simon and Schuster. [DOI:10.1145/358916.361990]

Rodríguez-Pose, A. \& Von Berlepsch, V., 2014. Social capital and individual happiness in Europe. Journal of Happiness Studies, 15(2), pp. 357-86. [DOI:10.1007/s10902-013-9426-y]

Roh, H. W., et al. 2015. Participation in physical, social, and religious activity and risk of depression in the elderly: A community-based three-year longitudinal study in Korea. PloS One, 10(7), p. e0132838. [DOI:10.1371/journal.pone.0132838]

Rudolph, C. W., 2016. Lifespan developmental perspectives on working: A literature review of motivational theories. Work, Aging Retirement, 2(2), pp. 130-58. [DOI:10.1093/workar/ waw012]

Sahaf, R., et al. 2014. Validity and reliability of self-report physical activity instruments for Iranian older people. Salmand: Iranian Journal of Ageing, 9(3), pp. 206-17. http://salmandj.uswr. ac.ir/article-1-778-en.html

Salvy, S.J., et al. 2009. Effect of peers and friends on youth physical activity and motivation to be physically active. Journal of Pediatric Psychology, 34(2), pp. 217-25. [DOI:10.1093/jpepsy/jsn071]

Schuch, F., et al. 2017. Physical activity and sedentary behavior in people with major depressive disorder: A systematic review and meta-analysis. Journal of Affective Disorders, 210, pp. 139-50. [DOI:10.1016/j.jad.2016.10.050]

Statistical Center of Iran. 2018a. [Census 2016 general results (Persian) [Internet]. Cited 30 August 2021, https:/ / www.amar.org.ir/

Statistical Center of Iran. 2018b. [Country's elderly status (Persian) [Internet]. Cited 30 August 2021, https://www.amar.org.ir/ news/ID/5241/

Sciamanna, C. N., et al. 2017. Physical activity mode and mental distress in adulthood. American Journal of Preventive Medicine, 52(1), pp. 85-93. [DOI:10.1016/j.amepre.2016.09.014]
Sforza, E., et al. 2016. Risk factors of osteoporosis in healthy elderly with unrecognized obstructive sleep apnea: Role of physical activity. Sleep Medicine, 22, pp. 25-32. [DOI:10.1016/j. sleep.2016.04.010]

Shi, Z., 2016. Does the number of children matter to the happiness of their parents? The Journal of Chinese Sociology, 3(1), p. 16. [DOI:10.1186/s40711-016-0031-4]

Sjörs, C., et al. 2014. Perceived reasons, incentives, and barriers to physical activity in Swedish elderly men. Interactive Journal of Medical Research, 3(4), p. e15. [DOI:10.2196/ijmr.3191]

Takechi, S., et al. 2017. Relationship between social capital and cognitive functions among community-based elderly. Advances in Alzheimer's Disease, 6(2), p. 45-51. [DOI:10.4236/ aad.2017.62004]

Torres, A., et al. 2013. The Ciclovia and Cicloruta programs: Promising interventions to promote physical activity and social capital in Bogotá, Colombia. American Journal of Public Health, 103(2), pp. e23-30. [DOI:10.2105/AJPH.2012.301142]

United Nations (UN). 2012. Population ageing and development 2012 [Internet]. Cited 30 August 2021, http://www.un.org/ en/development/desa/population/publications/ageing/ population-ageing-development-2012.shtml

United Nations Population Fund (UNFPA). 2019. Ageing report on Iran [Internet]. Cited 30 August 2021. https://iran.unfpa. org/en/publications/ageing-report

Vagetti, G. C., et al. 2014. Association between physical activity and quality of life in the elderly: A systematic review, 2000-2012. Brazilian Journal of Psychiatry, 36(1), pp. 76-88 [DOI:10.1590/1516-4446-2012-0895]

World Health Organization (WHO). 2012. World Health Day 2012-active ageing: Good health adds life to years [Internet]. Cited 30 August 2021. http:/ / www.euro.who.int/en/who-we-are/ whd/past-themes-of-world-health-day/world-health-day2012-active-ageing-good-health-adds-life-toyears

Woolcock, M., 1998. Social capital and economic development: Toward a theoretical synthesis and policy framework. Theory Society, 27(2), pp. 151-208. [DOI:10.1023/A:1006884930135] 